\title{
Public Policies \& Plans Study Regard to the Conservation of Shophouse Townscape in George Town, Pulau Pinang: Assessment, Limitations, and Current Issues
}

\author{
Loong Zhao, Zulkifli B. Hanafi, Hongwei Wong \\ Faculty of Architecture and Built Environment, Infrastructure University Kuala Lumpur, Kajang, Malaysia \\ Email: urbanplanning@vip.163.com, zulkiflihanafi@iukl.edu.my, hwwong@iukl.edu.my
}

How to cite this paper: Zhao, L., Hanafi, Z.B. and Wong, H.W. (2018) Public Policies \& Plans Study Regard to the Conservation of Shophouse Townscape in George Town, Pulau Pinang: Assessment, Limitations, and Current Issues. Journal of Geoscience and Environment Protection, 6, 73-100.

https://doi.org/10.4236/gep.2018.610006

Received: September 25, 2018

Accepted: October 28, 2018

Published: October 31, 2018

Copyright $\odot 2018$ by authors and Scientific Research Publishing Inc. This work is licensed under the Creative Commons Attribution International License (CC BY 4.0).

http://creativecommons.org/licenses/by/4.0/

\begin{abstract}
The conservation of townscape in George Town usually involves the enforcement of public policies and plans, which facilitate the conservation work in a sustainable and scientific way. In the recent decade, it has been increasingly recognized that public policies and plans in heritage sites have the significant impact on urban scenery, ethnic identity, and heritage sustainable development. However, the enforcement of public policies and plans in order to achieve successful townscape conservation is still insufficient in George Town. This study aims to assess the public policies and plans in relation to the townscape from the federal level to local level, and in turn, showing the current issues which caused by the deficiency of public policies and conservation plans. To ensure the objectives achieved, qualitative methods will be applied, including several approaches such as site investigation, cross-referencing, extrapolation and interpretation method. Empirical findings suggest that townscape in George Town should be ensured by implementing prudent public policy. Nevertheless, the current public policies and plans are inefficiently run, and various problems arise in the townscape such as de-contextualization, loss of authenticity and cultural integrity, Disneyfication, and environmental deterioration etc.
\end{abstract}

\section{Keywords}

Shophouse, Townscape, Public Policies, George Town, World Heritage Site

\section{Introduction}

In George Town, many local scholars have completed some related studies or 
conservation projects on built heritage in the past which focused on heritage conservation, restoration, and regeneration. An interesting observation is that, in many studies, there have been no published papers on the assessment of public policies and plans over recent decades. There is no doubt that the listing of George Town as UNESCO World Heritage Site on 7 July 2008 has put Malaysia as of the country to promote heritage tourism. Nonetheless, the prosperity in heritage tourism drive the local economy to a higher level, in parallel to this, new challenges and issues arising in this process. Scholars have noted that the urban heritage conservation in Malaysia is still a relatively new field [1], and the challenges we face today, particularly in a context characterized by turbulence and instability, are related to three orders of change: Demographic changes (population growth, urbanization); structural changes (globalization, growth of trade and relations, economic growth in-emerging countries); environmental changes (climate change, pollution, degradation of natural resources) [2]. Public policies and plans of conservation that have led built heritage to as tourism products are the reason for policymaker relative lack of success in conservation.

More broadly, the enforcement of the public policies and plans served a dual purpose. On the one hand, they emphasized the heritage significance through the physical environment. On the other hand, they offered a management strategy that facilitated a sustainable heritage development. As we have seen, there is no specific act or regulation for the overall shophouse townscape in George Town, or more precisely, the conservation work towards old shophouse block is inefficiently run under the current public policies or plans. As a result, the degrade of townscape quality results in an enormous changing of heritage site in every direction; even it has the significant status of UNESCO World Heritage Sites. Highlighting the above issues, the authors of this study paid more attention to the public policies and plans which regard to the shophouse townscape. The analysis based on the previous studies, literature review, interpretation of primary data, and analysis of the related heritage conservation policy, and then discussed the extent and depth of public policies and plans which influence the townscape in George Town.

\section{Literature Review}

\subsection{Shophouse}

In the Oxford Dictionary, the term "shophouse" is defined as (in Southeast Asia) a shop opening on to the pavement and also used as the owner's residence, which belongs to the residential and commercial sector [3]. This term was never used even in the local building by-laws since nineteenth century such as the $\mathrm{Mu}$ nicipal Ordinance (1887) in George Town, alternative terms were used instead, for instance, the nineteenth century writers used "long rows of queer little Malay and Chinese cottages", or "compartments ... single pigeon holes alongside the streets". The term "shophouse" has become common usage since the 1950s [4]. Singapore researchers from the National University of Singapore notes that the 
shophouse is a quintessential urban vernacular form [5]. Likewise in the view of David P. Y. Lung (2016), professor from University of Hong Kong, states that shophouse is one type of urban vernacular architecture and hybrid building as well [6].

Shophouse is strongly associated with Chinese traders and shopkeepers and, in fact, the term originates from "tiam chhu", which is a Hokkien term, meaning "shop" and "house" [7]. The Chinese shophouse is mainly two to three floors in height, with a certain typical interior layout. The shophouses are built along the street with an established uniform grid. The long rectangular floor plan of shophouses offers a narrow frontage. The ground floor, which faces the street, is for commercial purposes, whereas the rear section and upper floor of shophouses are for private use [8].

Shophouse, in this study, refers to the George Town's old "mixed-use" buildings which consist of dwellings and commercial space in one building structure in Malaysia, Southeast Asia. What is unique to George Town is the cohesiveness of the historic center with its intact row of shophouses and townhouses built in the nineteenth and twentieth centuries still dominating the townscape of the inner city. George Town is constituted by a higher proportion of shophouse, and these old buildings play a key role in establishing the identity of places. In the core zone of this study, the number of shophouse buildings are 4048, which account for $74.43 \%$ of the total. As such, as a remarkable example of a historic colonial town, George Town demonstrates a succession of historic and cultural influences arising from its former function.

\subsection{Townscape}

Townscape has a meaning that associates with a variety of concerns in environmental design ranging from the conservation of pre-industrial towns to the development of design guides for residential areas. The Oxford English Dictionary cites 1880 for the first use of the word "townscape", and 1889 for its specific use in the current sense. Thomas Sharp is an important scholar in this area, as he wrote in 1940, “ $\ldots$ by an analogy with an equivalent art practiced by the eighteenth improver of land, it might be christened townscape ... each street, in other words, must be judged as a single composition, as a single picture. And the word picture is important here, for curiously enough it is on the question of picturesqueness that the traditional continuous street has generally been condemned of recent years" [9]. Sharp admired townscape is connected with the diversity of its buildings as well as what they have in common. Ivor de Wolfe (1963) labeled townscape as a visual art, in his book The Italian Townscape, he defined townscape as "the greatest of all human activities, the building of a private, specifically human environment is against all the preconception of nature, if a town is that environment, townscape is the art of relating the eye to its possibilities" [10].

By the early 1950s, townscape had come to mean a theme of urban design 
which emphasizes the visual perception of the environment. The assumption was made at this time (similar to the contemporary assumptions about planning) was that the visual perception and consequent "improving" can be accomplished in an objective manner through an understanding of the emotional effects created by the juxtaposition of physical elements of the environment. Gordon Cullen (1953) defined "townscape" by stating that "one building is architecture but two buildings are townscape ... multiply this to the size of a town and you have the art of the environment" [11]. Cullen (1961) narrated the townscape like a dramatic scene, that is, there is an art of relationship just as there is an art of architecture, its purpose is to take all the elements that go to create the environment: buildings, trees, nature, water, traffic, advertisement, and so on, and to weave them together in such a way that drama is released [12]. Despite the emphasis was on "visual planning", what initially distinguished townscape from urban design, however, was theoretical content: a sensibility about the unique phenomena of place, the material, social, and temporal complexity of the city, and the democratic ideals of the inclusivity of everyday urban life [13].

More significantly, 1958, at the University of Pennsylvania, Ian McHarg's proposal for a comprehensive reconsideration of the field of landscape architecture for the postwar world was particularly influenced by townscape theory, which, following "Downtown is for People" [14] at that time, McHarg associated with Jane Jacobs and Grady Clay, and argued that the term "townscape" describes the human view of the city, the consciously and unconsciously created vistas and prospects, of buildings, spaces and buildings, street trees, street furniture, fountains, benches, sculpture, textures of materials, lighting, changes of level, the myriad of smaller constituents of visual experience in the city [15]. After McHarg, Pamela Ward (1968) defined the term as the total landscape of the town, it's natural and man-made ingredients and those which are a combination of both [16]. He noted that as a science, townscape consists in the studying and recording of all the elements (from buildings, groups, spaces, and variations in level, down to details like street furniture and lettering) which give a town it's individual character. Besides, Ward further described the standards of townscape from two aspects, the first one is the sense of place, the sense of place should make the people have a clear understanding of "where he/she is" when they are experiencing the town scenery from the physical setting and culture background, "gives us a sense of wonder and makes us want to know more about people and culture that produced it", it should be "possible to distinguish". The second one is the sense of unity, that means the representation of townscape is not a series of disconnect fragments or pieces, but as a whole, with the integrity of landscape characteristics, urban fabric, spiritual elements, contextuality and "the timeless quality of the buildings" [17].

More broadly, townscape what we talk about with built heritage background is associated with a group of quaint architectures with physical and social characteristics, historical figures or events, unspoiled urban vernacular buildings, co- 
lonial buildings distribute in the downtown area, along a river or coastline in some historic cities and thus convey simplicity, quaintness, sense of culture or romanticism characters which derived from region history, cultures by physical appearance and even coexistence with intangible ethnic personality, tradition, spirit, ideology in a deeper layer. For the purpose of this research, townscape is defined as the physical and social characteristics of the built urban environment and the hard and soft open spaces within it, together with the way in which people perceive those characteristics. It is this mix of characteristics and perceptions that make up and contribute to townscape character and create a sense of placeoridentity.

\section{Purpose of Study and Study Area}

According to ICOMOS Concept Note for the United Nations Agenda 2030 and the Third United Nations Conference on Housing and Sustainable Urban Development (Habitat III) on 15 February 2016, the contemporary issues around the world in urban heritage conservation mainly concentrated in eight aspects (Figure 1). Besides, Prof. David P. Y. Lung (2016) classifies the shophouse as urban vernacular architecture, he illustrates that the survival of the traditional vernacular architecture is unequivocally threatened by forces like rapid urbanization, uncontrolled population growth, degradation of our environment, natural disasters, economic pressures from high land prices and subsequent urban renewals, globalization, and the homogenization of culture. Furthermore, human neglect, ignorance, greed, wars, and conflict have hastened the destruction and replacement of the vernacular cultural heritage.

In the past, conservation practices and studies in George Town focused primarily, or sometimes exclusively, on the monument sites, heritage buildings, memorial landmarks of the local. However, studies in relation to the public policies toward townscape are limited, although series of international charters, declarations or resolutions enacted by ICOMOS, UNESCO and other important cross-international organizations year by year. A key feature of the conservation study in the recent decade is that shift its emphasis from the monumental architecture to the overall townscape, from conservation to the public policy, from community participation to the heritage democracy, and those are the new trends that conservators should follow in the conservation practice, what is more, exam the work on time.

George Town includes about 5000 units of two or three-storey shophouses where the residents used to work downstairs, typically in their family business, and live upstairs. According to the Special Area Plan: George Town, Historic Cities of the Straits of Malacca in 2016, shophouse blocks are generally classified into the Category II in the heritage building category (Figure 2). In the foregoing, the number of such buildings and sites are 4048 , which cover $74.43 \%$ of the total. Hence, in this regard, the study area is confined in the core zone (109.38 hectares) of world heritage site, bounded by the Penang Strait in the 
northeast and southeast, and Gat Lebuh Melayu, Jalan Dr. Lim Chwee Leong in the southwest.

In George Town, Malaysian Chinese constituted the majority of the population and they were the main ethnic community built and lived in the shophouse in history. This paper is a preliminary study, in this paper, public policy study is focused on the townscape of Malaysian Chinese shophouse blocks under the concept of heritage authenticity and integrity by its "Universal Outstanding Value".

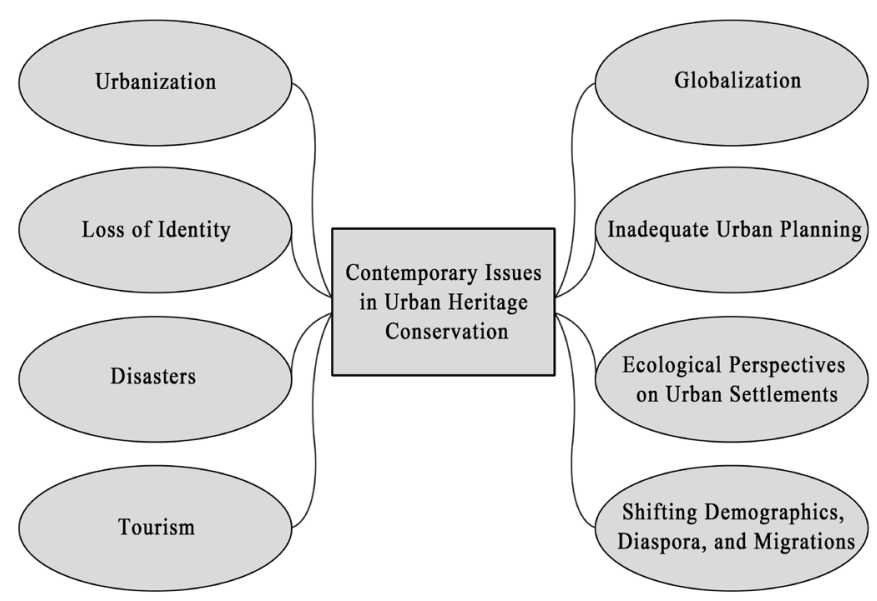

Figure 1. Contemporary issues in urban heritage conservation.

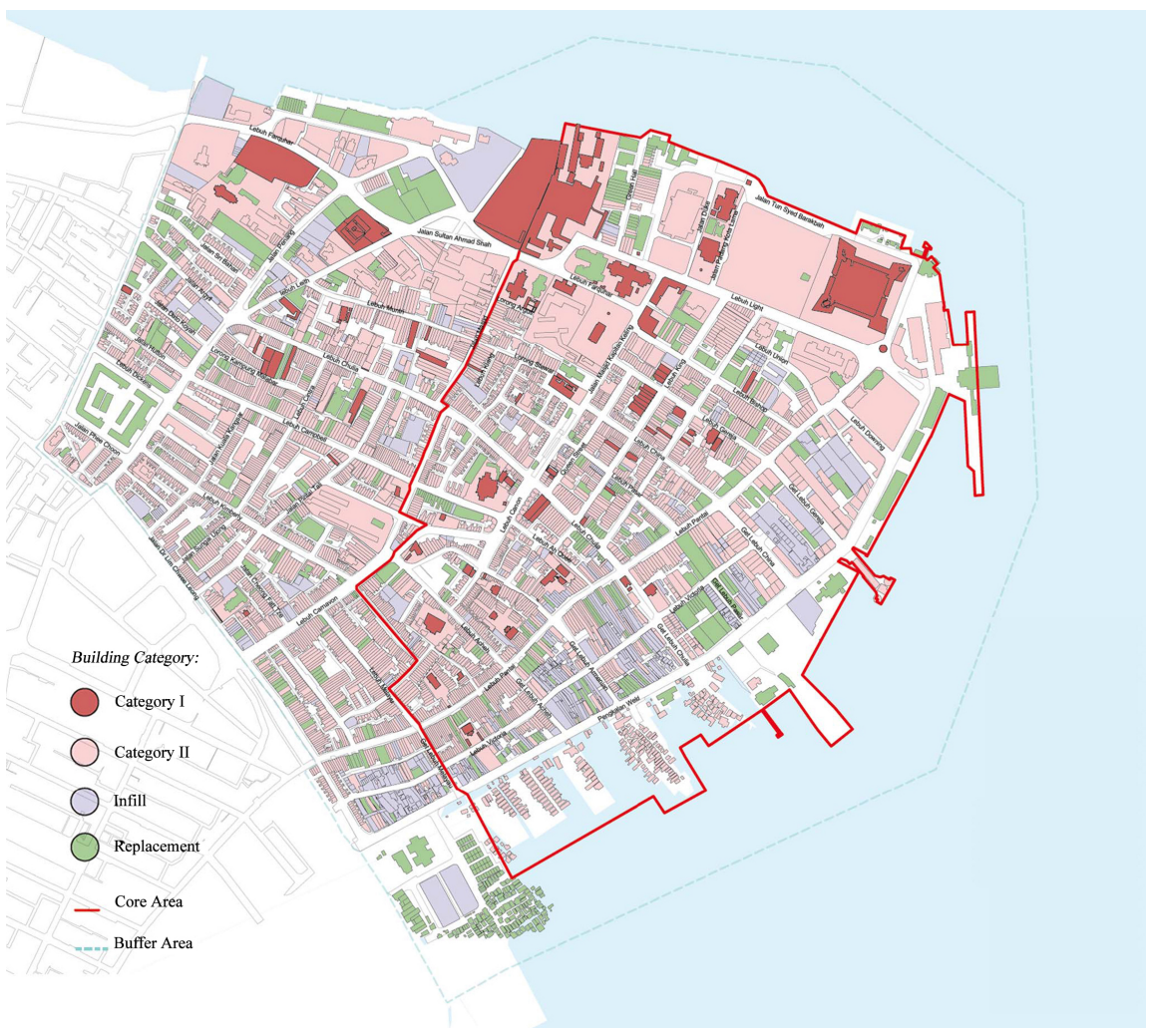

Figure 2. Distribution of Category II in George Town's heritage site. 


\section{Methodology}

A qualitative research methodology is selected to obtain the relevant study materials, it can provide empirical and direct proofs, and try to construct a framework of perceptual knowledge. Site observation, investigation, cross-referencing, primary \& secondary study, and extrapolation are conducted to understand the brief conservation history of shophouse blocks, reviewing the public policies and plans in the past and present, and in turn, showing the limitations and current issues in the conservation process of shophouse townscape.

\subsection{Site Investigation}

Extensive site investigation is carried out to establish the visual townscape image of the study area from dot, line and zone scale (Table 1). Site measurement is carried out in different blocks, and street characteristics, building components, styles and conditions or status are recorded in the process. Photograph of townscape, shophouse or other historic urban landmarks is taken separately to create as accurate as possible an urban morphology image.

Table 1. Public policy study from dot, line and zone scale.

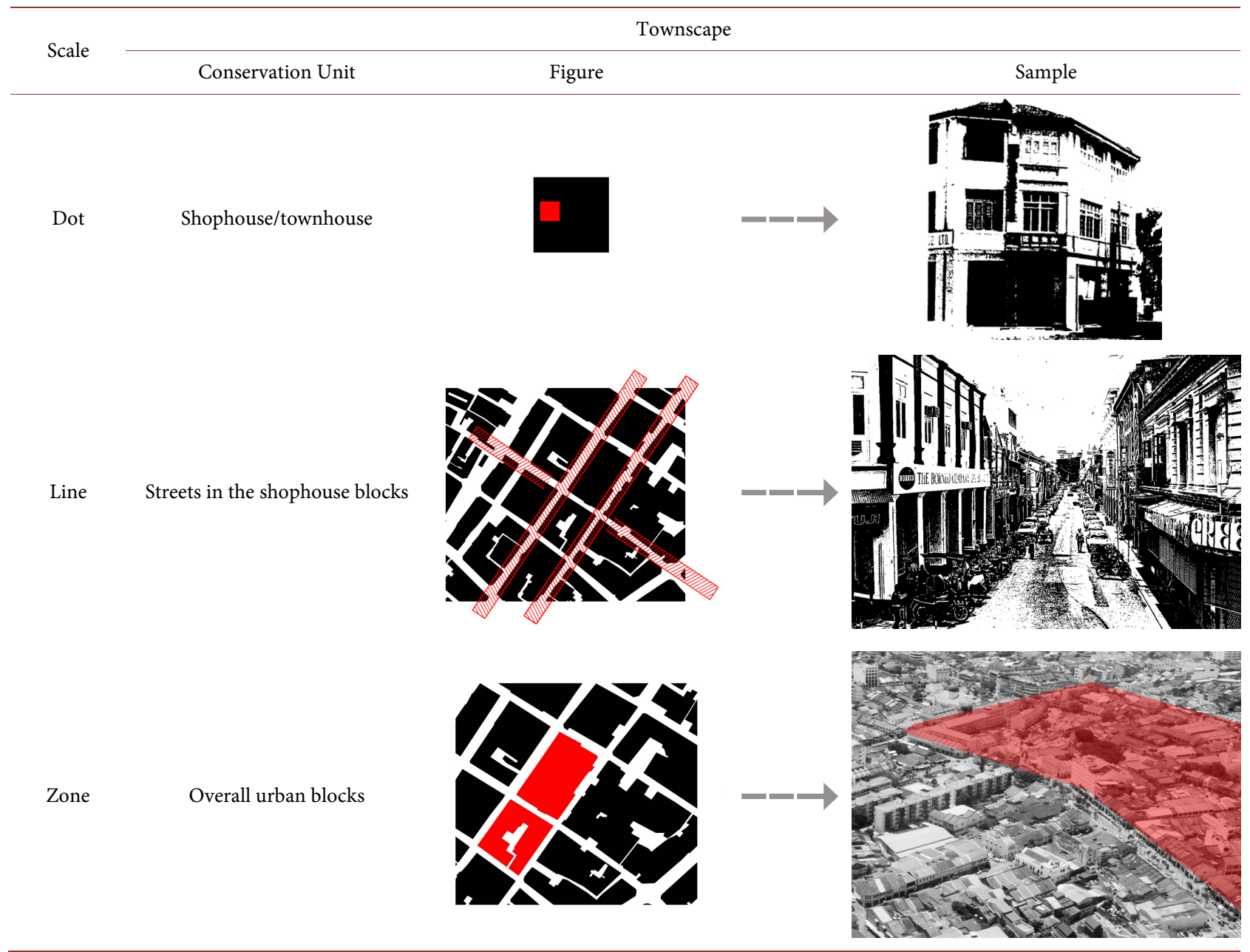




\subsection{Cross-Referencing}

A documentary research from published and unpublished sources (such as technical reports etc.) is carried out for a more detailed information. Technical reports and research papers on related studies available are also consulted for the purpose. Details on the shophouse construction and structure, heritage management and development plan, income and expenditure of public finance are obtained. Empirical data collected from the site investigation is cross-referenced with records from documentary research to ascertain the information is objective. Photographs taken on site are also compared with public policies, plans, and photo archives to ensure an accurate dimension of assessment as well as the accuracy of the overall townscape composition. The accumulation of basic data from cross-referencing will help to understand the current status and issues between the townscape and public policies.

\subsection{Extrapolation and Interpretation}

This cross-referenced data is then extrapolated and interpreted within heritage site's real status, and forming a discussion framework for the limitation of public policies and plans, and current issues such as Disneyfication, de-contextualization, environmental deterioration, and degradation of urban aesthetic quality. The interpretation of legal texts can obtain the heritage conservation information from the government. To some extent, it encompasses interpretive studies with a comparative and historical bent in the timeline, offer us a chance to review or inspect the legal framework, policies and methods, even the results and the possible trend in the future, thus, changes or adjustments will be made to lead a scientific and reasonable way in the practice. In addition, to increase the validity of this research, a software package (EndNote) is used in the data analysis process. This tool is very useful for carrying out quick and accurate searches of a particular type of information. It can enhance the validity of qualitative research through its capacity to provide systematic processes and procedures that offer higher accuracy and greater transparency.

\section{The Contribution of Public Policies and Plans to the Townscape: A Review}

This review section is divided into two parts, Firstly, a summary and comparison of public policies and plans in the past and present, and the relationship between public policies, plans and the shophouse townscape are presented (Table 2). The focus of the discussion is generally on the differences and/or similarities between public policies and the relationship toward shophouse blocks. When there was clearly a difference between the public policies, or policy and heritage interaction, this has also been noted. Secondly, an overview of the actual effect of the main public policies and plans is discussed.

In this review, we can stand at a macro-perspective from the federal level to 
Table 2. Comparison of the main public policies and plans in the past and present.

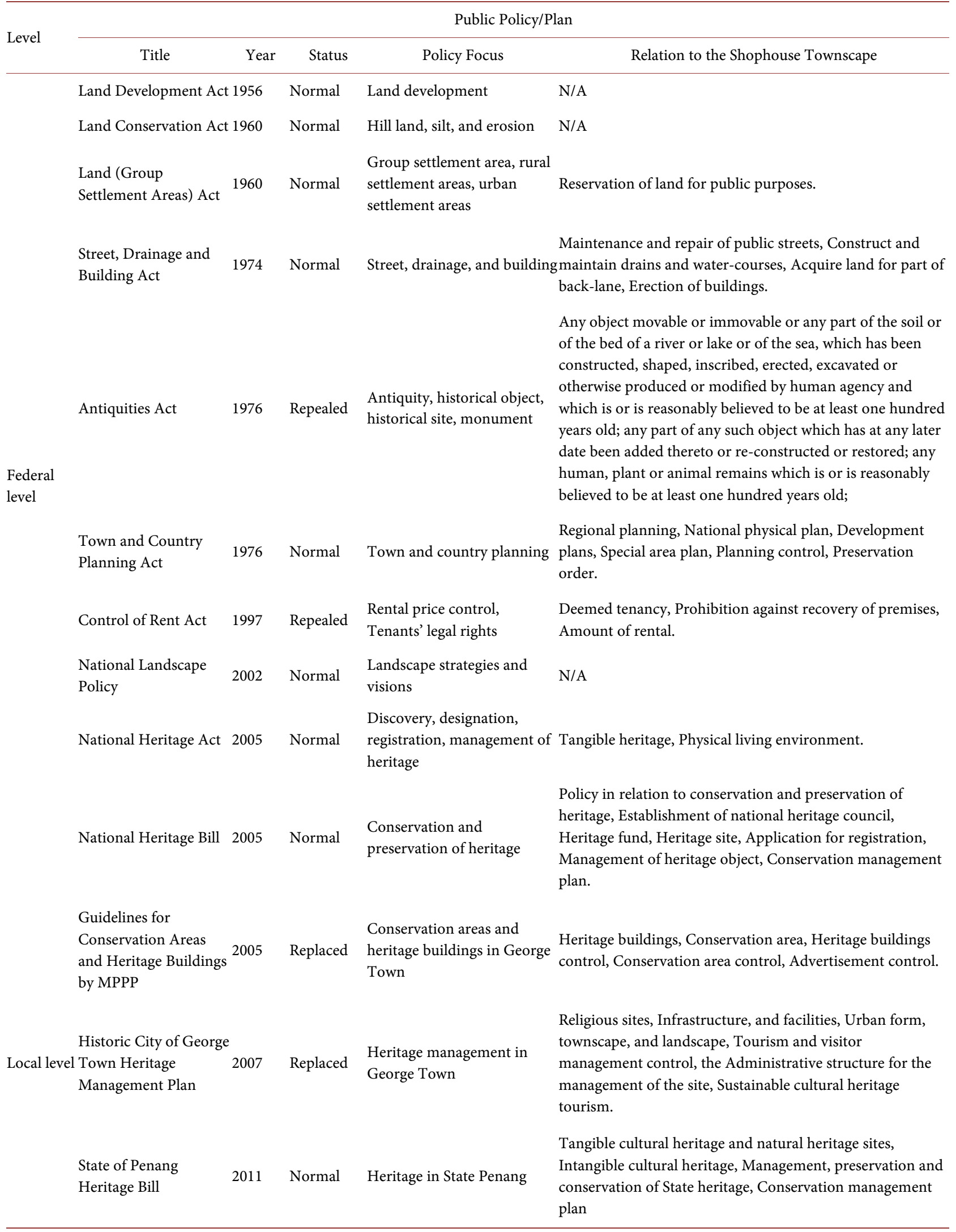


Special Area Plan: George Town, Historic 2016 Normal Heritage management in Cities of the Straits of 2016 Normal George Town Malacca
Outstanding universal value, Multi-culturalism and religious pluralism, Architectural landscape, Historic port cities, Built heritage conservation, Urban infrastructure and utility, Planning control, Building control, Legal provision for heritage conservation, Public participation, Protecting historic compounds, boundary walls, gateways, pathways and street furniture, Improving urban infrastructure, traditional cultural festival etc.

the local level. At the federal level, it includes Rent Control Act (Repealed), Antiquities Act (Repealed), Street, Drainage and Building Act 1974, Town and Country Planning Act 1976, National Heritage Act, National Landscape Policy and National Heritage Bill 2005. At the local level, it includes Guidelines for Conservation Areas and Heritage Buildings by the Municipal Council of Penang, Historic City of George Town Heritage Management Plan, Special Area Plan: George Town, Historic Cities of the Straits of Malacca 2016, State of Penang Heritage Bill 2011.

An important point to make here is that most of the current conservation and preservation efforts or actions are concentrated mainly on landmarks like historic buildings (City hall, High court, Masjid Kapitan Keling, St. George's Church, Church of the Assumption etc.), historic sites (Kota Cornwallis etc.) rather than the townscape from the perspective of the overall urban area.

\subsection{Rent Control Act (1948): From Enact to Repeal}

There was no actual measure to preserve the shophouse buildings in George Town before the1980s. As we have seen, a large number of shophouse have been preserved until today not because the heritage awareness rising or conservation decrees from the government sectors, but the existence of Rent Control Act in a specific social background. Down to the1990s, the Rent Control Act maintained the integrity and authenticity of the shophouse buildings indirected and in-directed way and controlled the initiatives of land development in the historic urban area. This act covered nearly 12,500 buildings in Penang state (about 66\% of which are in the urban area) and aimed to protect the rights and interests of tenants who rent a room or house in George Town, not the building itself. The landlord was not allowed to increase the rental price or expel the tenants, and the rental price was only $1 / 10$ of the normal market price. Rent Control Act avoided the rising of rental price and reduced social inequality. The poor and grassroots who were living in the old inner city could obtain a basic place to live and without worried about eviction from the shophouse suddenly by the landlord.

Most shophouse blocks and monuments in the old inner city were conserved by the Rent Control Act and the Antiquities Act (1976). Admittedly, the Rent Control Act ensured shophouse buildings in an original condition, however, it 
caused a majority of shophouse buildings dilapidated. The rent-controlled shophouse buildings usually survived well because of the disincentive for owners to demolish and rebuild their premises. Low benefits from the rent dispelled the enthusiasm of the landlord for any renovation, reconstruction, and restoration, to some extent, it played a positive role in the conservation of shophouse buildings, it slowed down the development of shophouse for other purposes. If the owner wanted to restore the shophouse and use it for any other purpose, he needed to submit an application to the rent tribunal according to section eighteen of the Rent Control Act and to obtain a permit through a long time procedure [18].

This policy was amended later, and the direct result was the promulgation of Act 572 (1997). It helped the owners to raise the rents to maintain and repair their old shophouse. The Federal Government of Malaysia was driven to repeal rent control for the whole nation without creating any other local option. From 1980 to 2000, after 20 years, the Rent Control Act was abolished in 1997. With the abolition of the act, the rental price reached a higher market price. In the Tun Dr. Mahathir era, the fact that control hampered urban redevelopment and underutilized scarce land capital for a long time was considered to be problematic. Thus, repeal of rent control was expected to reactivate flows of land capital by encouraging investment in pursuit of further economic development. In terms of the ethnic problem in Malaysia, putting urban properties mostly owned by ethnic Chinese on the market after the repeal of rent control is supposed to mitigate the ethnic imbalance with Malays [19]. The deep concern that the elimination of rent control will add to pressures to develop old George Town with the loss of both the physical heritage and the social, cultural, and economic life embedded in the houses, religious buildings, and streets of the inner city [20]. The Minister for Housing and Local Government, Ting Chew Peh, read the bill for the repeal in April 1997. The Penang State Government had a strong desire to propel urban renewal with the end of rent control. Since most of the landlords of decontrolled premises in the inner city of Georgetown showed interests in developing their properties as commercial or office space, a change in the characteristics of the urban area as a result of the conversion of residential buildings for commercial uses seems to be inevitable. A majority of landlords also indicated their interest in redeveloping their properties for commercial use [21]. Transactions for prewar shophouse became very active after the abolition [22]. Meanwhile, government loan grants for landlords to refurbish their properties did not work as incentives for property owners.

The result was that many shophouses had been repaired and changed by the tenants and sub-tenantsun reasonably, the owner not merely changed the building function, facade and construction materials, but also led to the dilapidation. According to the statistics derived from Cornell Real Estate Review, the Municipal Council of Pulau Pinang found that 569 premises were vacated on 123 streets in George Town and there had been a substantial number of tenants among cof- 
fee shop owners, merchants, and craftsmen who had already closed their businesses [23], besides, the vacated buildings have become hotbeds for illegal occupation by homeless people, drug addicts, and vandals [24], accelerating the dilapidation of the old inner town. To go further, those who lived in the old shophouse had to move out, and the traditional trade atmosphere disappeared gradually. In addition, the tenants who had lived in these houses for several generations had also taken the cultural essence away while moving out. George Town lost its heritage attraction gradually when new changes come, heritage values gone.

\subsection{From the Antiquities Act (1976) to the National Heritage Act (2005)}

The Antiquities Act was promulgated in 1976 and was later replaced by the National Heritage Act (2005) (Act 645). This policy only applied to those states in west Malaysia (excluding Sabah and Sarawak), and it provided a preliminary legal framework for the "ancient monuments". The Antiquities Act focused on the conservation of antiquities and provided supports in the conservation process of monument sites which had significant heritage value. This act emphasized the time limit of ancient monuments that should be at least 100 years. Although it excluded the large area of George Town's shophouse blocks from the threshold of "ancient monuments", it played a positive role in conserving the historic landmarks which were built in the colonial era such as church, mosque, administrative building and old mansions, and it played a certain role in the maintenance of townscape indirectly. Section fifteen of this act emphasized that anyone was not allowed to dig, excavate, build, plant trees, quarry, irrigant, burn lime and other similar jobs without permission. For the demolition, interference, obstruction, modify, mark and pull down of the ancient monument itself, the movement of any part of the ancient monument, the alteration, addition, repairment and erect of new buildings or walls can only be built with permission.

However, this act had its own limitations. First, in the modern heritage conservation history, the conservation work started from single antiquities and single historic buildings such as a vase from the Ancient Aegean or a cluster of buildings from the Medieval Era, and then extended to the historic urban areas after WW II, to date, the focus is paid on the overall townscape. Even the UNESCO, ICOMOS charters or resolutions which were related to the conservation of built heritage were also experiencing such conservation course. Second, this was the trend of international heritage conservation movement in the 1970s. Obviously, it was inappropriate to criticize a legal document in history with present conservation concept.

In 2005, the Malaysia parliament promulgated the National Heritage Act which aimed to conserve the natural heritage, tangible and intangible cultural heritage and underwater cultural heritage, meanwhile, replaced the Antiquities Act. This policy interpret the cultural heritage signification, and stress that cul- 
tural heritage has aesthetic, archaeological, cultural, historic, scientific, social, spiritual, linguistic and technological values [25]. It over passed the limits of 100 years in the Antiquities Act, move over, extended the scope and definition of cultural heritage, new terminologies like "historical object", "conservation management plan", "archaeological relic", "safeguarding" are listing in the act. Meanwhile, it states that "conservation" includes preservation, restoration, reconstruction, rehabilitation, and adaptation or any combination. The townscape of shophouse blocks was constituted by tangible heritage outside and intangible cultural heritage (religion, ethnic tradition, livelihood, daily life routine etc.) inside. Although not described in detail, this policy is the main reference that categorizes cultural heritage according to the typology of values [26].

The contents in the National Heritage Act such as the designation of the heritage site, interim conservation order, dealings involving heritage site, conservation and preservation of heritage site, conservation area and conservation management plan generate strong impact on heritage conservation in Malaysia. It gives a legal basis for heritage conservation and played a positive role in the conservation of George Town's shophouse blocks. According to the provisions in this act, the development of the heritage site should be applied to the local planning department for planning permission, it stated that remove the whole or any part of a building or monument on the heritage site need a permission after consultation with the state authority. In section 46.1, two guidelines that relate to the townscape: 1) promoting the conservation, preservation, rehabilitation, restoration or reconstruction of a heritage site. 2) ensuring the proper management of a heritage site including the use and development of all buildings and lands in heritage site and the preservation of the environment including measures for the improvement of the physical living environment, communications, socio-economic welfare, the management of traffic and the promotion of economic growth. The cautious and mandatory regulations on land development in heritage sites have provided a basis for sustainable development of historic townscape.

\subsection{Guidelines for Conservation Area and Heritage Buildings (2005)}

In the Guidelines for Conservation Area and Heritage Buildings (2005), the core zone of heritage site was 99.35 hectares, and the buffer zone was 89.29 hectares. This guideline had made a complete statement on designation and conservation of heritage buildings, conservation areas and other elements which with cultural symbols or historical meanings. This guideline emphasized the basic principle of heritage buildings conservation in George Town, namely, maximum retention and minimum intervention. Such principal was effective in maintaining the integrity and authenticity character of townscape, and the true historic value was merged into the urban scenery. In practice, firstly, if the original building elements need to be repaired or replaced, it must confirm that the new martial is 
the same as the old one. Secondly, any reconstruction work is forbidden. Thirdly, if there is no existing preservation method to retain the original state of the heritage building, the change or dismantle work is forbidden. Fourthly, adaptive reuse of heritage buildings is worth encouraging and advocating. After all, in most instances, restoration, refurbishment or adaptive reuse is preferable to demolition of graded properties.

According to this guideline, the conservation criteria were listed in seven categories: I. historic interest; II. architectural interest; III. association; IV. townscape value; V. group value; VI. age and rarity; VII. the physical feature, layout, and material of the buildings and the location that can reflect the original design [27]. Additionally, these guidelines apply to all graded old buildings and places within the Municipality from the following dimensions: historical background, cultural traditions, historic buildings, and the overall townscape. Potentially, these guidelines show a systematic framework that interprets the relationship between built heritage and social background. This can be better understood if categorized under economic, cultural, and environmental, although they are not mutually exclusive and, indeed, they are often interlocked.

The Guidelines for conservation Area and Heritage Buildings put forward specific measures for heritage building control, conservation area control, and advertisement control. In terms of practice, it showed a clear regulation on maintaining the exterior and interior building details of shophouse such as roof, structure, ridge, exterior wall brush, skyline, windows, forecourt, front facade, rear facade, five foot way, stairs, pipes, air conditioner, and other decoration elements. To some extent, these regulations were useful and necessary for the townscape.

\subsection{Historic City of George Town Heritage Management Plan (2007)}

The Historic City of George Town Heritage Management Plan was released in 2007, it had more advanced conservation standard than the former one - Guidelines for conservation Area and Heritage Buildings (2005). This plan emphasized that ensuring and encouraging sustainable heritage development, providing a conservation and development framework for safeguarding the authenticity and integrity of heritage sites, and exemplified a case of outstanding universal value. In order to conserve and enhance the townscape of cultural significance, the subdivide requirements such as authenticity and integrity were derived from the Nara Document on Authenticity (1994). It conveys a meaning that townscape in a heritage place includes both the listed heritage item and its associated overall heritage environment.

The core zone in this management plan had expanded from 99.35 hectares to 109.38 hectares, which covered the urban area from the northeast cape to the Lorong Love in northwest, and southwest to Gat Lebuh Melayu and Jalan Dr. Lim Chwee, with more than 1700 old shophouses, meanwhile, the buffer zone 
had expanded to 150.04 hectares as well. These changes finally confirmed in the Nomination Dossier - Historic Cities of the Straits of Malacca (2008), which submitted to the UNESCO in 2008. This management plan listed China town, the Indian settlement, Malay town, Harbor area (include Clay Jetties), Civic precinct, and the historic commercial center as special area separately. Among these areas, the Chinese town and the historic commercial center were located in the study area with shophouse buildings distributed widely, and the urban scenery was composed of commercial and residential shophouse buildings and other commercial buildings. As stated in this management plan, the dominant architectural form in George Town was shophouse, and these forms originated in southern China, as the Chinese population grew and became dominant, their influence and cultural requirements began to be reflected on the buildings in the townscape, move over, the physical form of the shophouses influenced by Feng Shui [28]. These interpretations facilitated the cultural depth of townscape in the conservation work.

\subsection{Special Area Plan: George Town, Historic Cities of the Straits of Malacca (2016)}

The Special Area Plan (SAP) is published in September 2016, it is the latest management plan for built heritage in George Town World Heritage Site which is more professional and detailed than the Historic City of George Town Heritage Management Plan in the contents. This management plan is divided into four parts, the first part interprets the history, heritage significance and SWOT analysis of George Town World Heritage Site; the second part states the conservation vision and management strategy; third part states the development guidance plan; the fourth part describes the guidelines for heritage buildings and conservation areas. Notably, the third part of SAP aimed to control the land use and development in the conservation area and to promote the goal of sustainable economic growth, at the same time, formulate strategies to meet the economic and social needs. It is apparent that the townscape was invested with historic significance by its inhabitants, and present generations meaningfully associated many of its buildings with events and figures from the recent and distant past. The townscape in the Special Area Plan was strengthened more than any other narratives in the past, it states that the existence of architecture added to the quality of our life, and continued the distinctiveness of local scenery by enhancing familiarity and cherishing local scenery, which was an important aspect in maintaining the city's characteristics and appearance [29].

The SAP divides the built heritage into two categories. The first category is landmarks, historic buildings and monument sites like Kapitan Keling Mosque, Queen Victoria Memorial Clock Tower, Fort Cornwallis etc. Which with a strong meaning in the townscape. The second category is the large-scale shophouse blocks, which are the main component of the townscape. In the townscape, the facade, five food way, original materials, window style and deco- 
ration of shophouse buildings should be maintained, restored and conserved according to the requirements of authenticity. In this regard, the SAP emphasizes the importance of townscape in maintaining the authenticity of shophouse blocks. The conservation contents arrange from building appearance, style, roofline, roofscape to the townscape and vista.

The SAP put forward a reference plan for the renovation of shophouse buildings and urban expansion without affecting the overall urban landscape and heritage features. Furthermore, it represents the maximum possibility of conservation of townscape and vista, such content is not mentioned in the past several conservation plans. A series of detailed methods are presented in the form of case study, and offer requirements and suggestions from the types, structures, components, decoration characteristics of buildings to the construction materials, repair materials, finishes, and colors.

\section{Findings and Discussion}

\subsection{Limitations of the Public Policy and Plan}

1) The neglect of public policies and plans on the overall townscape. As aforementioned, as early as 1976, the Antiquities Act had certain positive significance for the maintenance of townscape, although it was limited to 100 years if a place was to be nominated to an ancient monument. In the townscape, no single component can be neglect. In the modern conservation concept, the old shophouse blocks no doubt that fulfills the standards which with historic, extraordinary values, and reflect the social development and human civilization in different periods [30]. However, most shophouse blocks are less than 100 years, thus, they are not listed in the legal conservation framework and cannot be designated as an ancient monument. Certainly, a place would take a very long time to be considered as an ancient monument, but the concept of historic building or historic area did not necessarily need to be limited by the time frame. The National Heritage Act replaced the Antiquities Act in 2005, the scope and definition are extended in this new policy, but there is still an omit on tangible cultural heritage which includes area, street, monument, building, and the overall physical environment. More importantly, there are no clear definition regards to historic urban landscape or townscape.

The National Landscape Policy mainly focuses on natural landscape and modern urban landscape. Historic townscape which developed in a specific social and economic context, or by some ethnic groups, or under a cultural pluralism background need to neglect from the point of policymakers. In this point, same as other policies, it is normal to see that the townscape, historic urban landscape, and ethnic culture are omitted deliberately. Although the policy recognizes landscape as an aspect of economic benefits and social interests, and it is beneficial to both the people and the government, it should not be ignored that the cultural influence of townscape is also had a positive role. The world 
heritage site status of George Town is not because its green space or new residential area, but the historic buildings, the overall townscape, and cultural melting mechanism that had been constructed from the age of colonialism, no doubt, the townscape is the name card of George Town.

The Historic City of George Town Heritage Management Plan in 2007 involved the management of urban morphology and townscape. Most of the contents were about the improvement of the pedestrian environment in neighborhoods, and focusing on the improvement of the physical conditions in the existing urban areas. Rather, it should be a partial landscape and infrastructure improvement plan, but it had not played a substantive role in maintaining the townscape or landscape in the shophouse blocks. In Special Area Plan: George Town, Historic Cities of the Straits of Malacca (2016), the second part states the conservation vision and management strategy, the third part states the development guidance plan, and the fourth part describes the guidelines for heritage buildings and conservation areas, but improvement of the continuous facade, the disorderly advertisement, the actual practice of the concealed project in the shophouse blocks are not mentioned. Although the SAP proposes specific action strategies, implementation, and monitoring measures, the relevant measure seems powerless and the discussion is superficial.

2) Lack of enforcement and cooperativity in public policy practice. From the 1980 s to 2008, the government sectors' efforts provided a legal framework for the conservation of built heritage in George Town. The designation of Malacca and George Town, historic cities of the Straits of Malacca, as a World Heritage Site in 2008 was welcomed as a major step forward. However, warnings by UNESCO officials that construction in the core and buffer zones of the sites could jeopardize the accolade [31] hint at the gaps between the rhetoric and realities of conservation policy. In practice, public policies, guidelines, and plans were failed because these documents were only "documents" and there was no legal enforcement. What's worse, the renovation work without the permission of the municipal government finally led to a large number of illegal projects constructed in the historic urban area. In the old town center, it once occupied by rows of old shophouses, due to the lack of appropriate legal constraints, the dominant role had gradually lost. The scenery of the shophouse blocks in rows was destroyed by newly built buildings and improper renovation, which had irreparable impacts on the overall townscape.

Scholars have noted that the public policy of heritage conservation is characterized by a high degree of policy integration. Such system covers all the process of policy making, implementation, comprehensive plan \& design, and executive system, which integrate almost key economic, management departments, and legislative branch. The linkage between the federal government and the state, the direct policy and the related policy still remains rather obscure. The public policy and plan have not formed a joint force on the conservation of townscape. Therefore, without an effective mechanism, it is impossible to propose flexible 
solutions, issues relating to design, building form, height, setback, car parking, and landscaping for existing buildings and places cannot be solved on time.

Furthermore, it is notable that there is no effective public policy in the townscape conservation field, the practice only relying on the conservation plans which issued by local departments or organizations, heritage conservation standards like a vase in the shop window. It is a paradox that the heritage administrator imagines it can constrain the illegal renovation, such Utopian conservation methods will lead conservation work to a wrong way, as a result, with the inconsistent conservation plan, and coupled with the mandatory prohibition renovation of shophouses in the past, many vacant shophouses were abandoned. At present, the number of deserted or dilapidated shophouse is gradually increasing, and there are lots of empty shophouses distribute in the core zone and buffer zone which has not been managed and repaired. Hence, it is necessary to provide sustainable solutions to relieve such dilemma. Once lost, the townscape cannot be replaced.

3) The contents of related policies are not comprehensive enough to retain the existing townscape. The main function of shophouse is business and residents, and their activities, life behaviors, life styles are changing with the time, and enrich the landscape connotation of the scenery [32]. The conservation of townscape is generally perceived to be in the long term interest of society. Hence, heritage conservation should not act to prevent change, but rather to shape change in an appropriate and sympathetic manner. The latest Special Area Plan: George Town, Historic Cities of the Straits of Malacca (2016) is the most perfect edition of conservation plan in George Town, but four parts in the contents that are still insufficient. The main discussion can be formulated as follows:

First, the intangible cultural heritage associates with the physical environment of shophouse block is not integrated into the public policies or plans in the practice field. The question of the relationship of tangible and intangible heritage has been recently taken as a topic of discussion in the townscape. To gain that insight, however, it is necessary to acknowledge the role of intangible cultural heritage. Despite there are numerous valuable historic assets, but tangible pieces of built heritage within small towns is often underestimated and overlooked. The UN notes that urban heritage includes urban parts (urban morphology, open green space, urban infrastructure), building parts (monuments, buildings) and intangible parts [33]. Cultural heritage in physical and intangible form are interdependent with each other when intangible cultural elements in the physical forms are understood and respected by the public. To some extent, the method of combining townscape conservation with intangible cultural preservation, offers a tool that is useful in both heritage authenticity and integrity. Townscape conservation work such as restoration, renovation of methods with traditional technologies and materials, traditional festival, common daily life, could strengthen the city's symbolic images, they are recorded and transmitted in a dynamic way with historic significance of material production, lifestyle, ideas, customs 
and social habits, and become a living witness of history.

Second, overall control in the townscape is insufficient. An interesting observation is that, control over significant urban historic fabric to interiors is normally only exercised in those instances where the place has been identified as being of state significance, in parallel to this, more broadly, townscape need overall control as well which refers to the evident persistence of monuments and physical signs of the past and changes over time in the whole region. A comprehensive control in the soundscape, colorscape, even illumascape is important for townscape. In the recent decade, studies toward the acoustic environment of historic blocks have gradually become an important aspect of townscape conservation which play significant value in public policies. Jane Jacobs once wrote, when we think of a city, the first thing that comes to mind is the street, cities with lively streets are lively, and cities with dull streets are dull. Jan Gehl pointed out in his book Life Between Buildings (1971) that when the background noise exceeds $60 \mathrm{~dB}$, it is almost impossible to have a normal conversation. Moreover, lack of colorscape study to the overall urban color management, color planning, and color evaluation. The traditional color of shophouse blocks reflects the color preference of ethnic community, life philosophy, custom, and aesthetic concepts, which is an important parameter in the history information system. With the regeneration of urban image or local scenery, conservators should improve the decision of color planning or management in the policy, so as to continue and inherit the historic features, and restore the overall townscape effectively. In fact, George Town lagged behind in promoting the management of soundscape and colorscape which cannot be integrated into the public policies and plans to guide the heritage conservation work.

Third, the concealed work is still insufficient in the historic urban area. In the past, more principles focused on the installation of billboards and air conditioners on the building facades. In fact, in the townscape, urban underground pipe grid and power transmission lines are both important aspects that affect the landscape quality. Urban underground pipe grid in George Town included water supply, drainage, gas, electricity, and industrial pipelines, these municipal infrastructures can be classified as the concealed project, however, the local government failed to pay enough attention in the past, thus, the problem is more serious and hard to solve today.

4) Public policy is unable to meet the intensive and high efficient needs of historic urban areas. In the contemporary conservation context, the planning process is increasingly focused on balancing two important considerations: a) the need for long-term new development, and b) the need to conserve built heritage. In George Town, the conservation development conflictor conservation dilemma is further complicated by the plurality of cultures within the city, all with their own claim to a unique heritage. Yet this historic built environment was not static, but subject to destruction and redevelopment. If a relevant, up to date conservation plan already exists for the site, its recommendations should 
form the basis of any decisions with respect to demolition and redevelopment. The heritage assets are encouraged to reuse in an intensive and high efficient way, namely, adopts the combination methods of conservation, renovation means, dynamic renewal modes with mixed function, so as to make the block functions to meet the present requirements. As a precious cultural asset, shophouse blocks are the social capital and driving force in the local level. It is generally considered that shophouse is personal property, but the townscape is public interest. In this sense, most landlords lack of motivation in supporting relevant conservation policies.

Cultural heritage is often seen as an economic resource which is ripe for exploitation. As far as the shophouse blocks are concerned, there are serious problems in its livability and sustainable development ability. The increasing reuse of historic sites within new developments, as a marketing tool and economic generator, has served to question old assumptions concerning the division between redevelopment and conservation [34]. The government intend to revitalize these areas for heritage tourism, in addition to this, it can be encouraged to develop the creative industry in the old buildings as well such as advertising, architecture, art, crafts, design, fashion, film, music, performing arts and publishing, meanwhile, accompany with pubs, coffee shops, tea houses, and bookstore.

5) The financial support for the maintenance of townscape in George Town was limited. For townscape, governments in different levels are the main body to offer the financial support and attract investment from the private sectors. Throughout the world, a number of historic cities which has systematic administration in conserving built heritage, they tend to pay special attention to the financial funds and increase the investment into the urban budget. The National Heritage Act states that an owner of a heritage building may, for the purpose of carrying out any conservation and preservation works on the heritage site apply to the commissioner for any grant or loan. However, the dilapidated shophouse, as we have seen, become more and more within the core zone. In shophouse blocks, the conservation investment is still far behind the growth of demand rate, and the shortage of fund always restrict the conservation work. The state funds should be the main part for heritage conservation, and the social fund which by private donation can only as the supplemented, without funds, conservation is just a meaningless term. But for local governments, the enthusiasm for investment in conserving townscape is out of interest generally, unless in the aspect of the tourism economy. Every year, the fiscal revenue from tourism can facilitate townscape conservation work in shophouse blocks, but the capital investment from fiscal revenue for townscape, to some extent, closefisted.

\subsection{Current Issues in the Townscape}

1) De-contextualization: the neglect of specific ethnic community culture. Neglect is another hazard, perhaps caused by insufficient resources and expertise [35], or nationalism. The collapse of western colonialism in the past century 
promoted the founding of Southeast Asia countries, these countries showed a completely opposite form compare with the formation process of European nation states. In Southeast Asia, the state dominates the formation of the nation and closely linked with nationalism. However, the newly independent countries in Southeast Asia were fragile and unstable, the political identity of citizens is not the same as the cultural identity of ethnic groups, even they are separated and conflicted, the ethnic relations are tense, the process of the country founding and the construction of self-identity are still in progress so far [36]. Heritage may serve to assist in unifying a disparate populace, but it can be divisive as a marker of ethnicity if the story of one group is privileged over others [37]. Economics and political cultures may also inhibit lobbying for the conservation of built heritage by those within government circles and society at large [38].

From the perspective of ethnology, each culture has its own ways of obtaining information and of representing its values, it can be likened to the umbilical cord of a clan, symbolize its spiritual resources and strength, which brings the essence of the culture of a group from generation to generation. When Chinese became the main population, Chinese shophouse in the urban areas was built rapidly as a new scenery in the township. As is shown in Figure 3, Chinese culture in the townscape is the most basic element of specific ethnic community, ethnic Chinese community has its unique cultural symbols, these symbols exist in the architecture, clothes, decoration, traditions, techniques, language and other forms of intangible heritage, as well as spirit and feeling or other issuesetc. Connection with familiar landscapes forms part of political and cultural identity, as people feel they belong to one place, one region, one country [39].

In fact, the government's action that enhance the national subjectivity of Malaysian Chinese through the heritage conservation become fewer and fewer. In George Town, Jenkins, G. (2008) notes that these "human legacy" were largely influenced by the decline of ports and the social development policy after Malaya's independence [40]. In a recent article, Taiwanese scholar points out that Malaysia has been strongly implementing a single nation cultural policy since its independence, and political considerations have become the main influencing factor [41]. Malay community prefer to the ethnic nationalism and try to build a nation with Malays as its core race while Malaysian Chinese strive for a more fairer and impartial society, with their civil rights on the basis of civic nationalism [42].

2) Loss of authenticity and cultural integrity in the townscape. The fundamental conditions for the qualification of cultural sites to the World Heritage List include the requirement to satisfy the notions of authenticity and integrity [43]. In George Town, although has prosperity in tourism in the past several decades which drive the local economy to a higher level, it raises other problems. As we have seen, a series of direct issues in the townscape are often associated with public policies insufficient (Figure 4). Kamal, K. S., Wahab, L. A. and Ghafar, A. A. (2008) carried out a survey on the historic buildings in Malaysia, and 


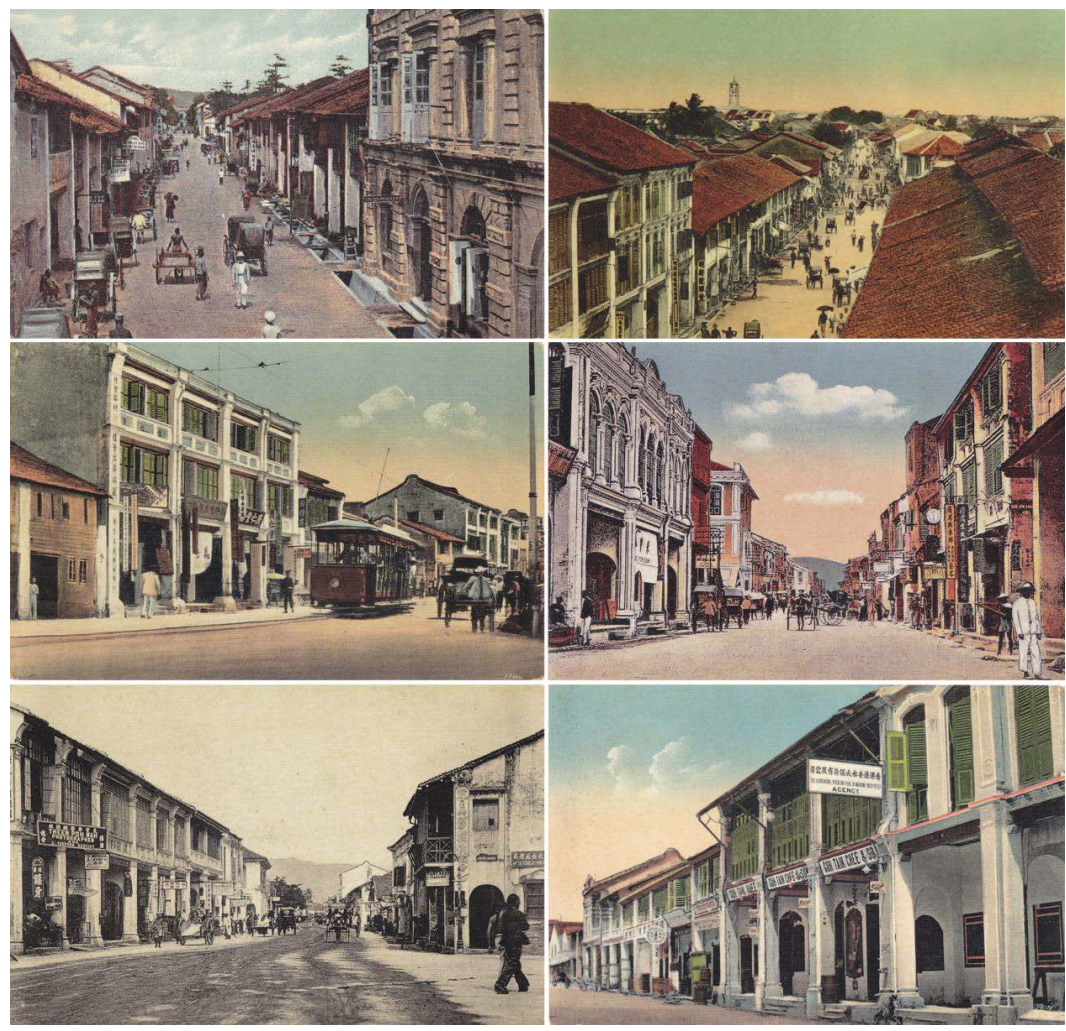

Figure 3. Townscape of George Town in 1899-1930s (Source: Jin Seng Cheah, 2012).

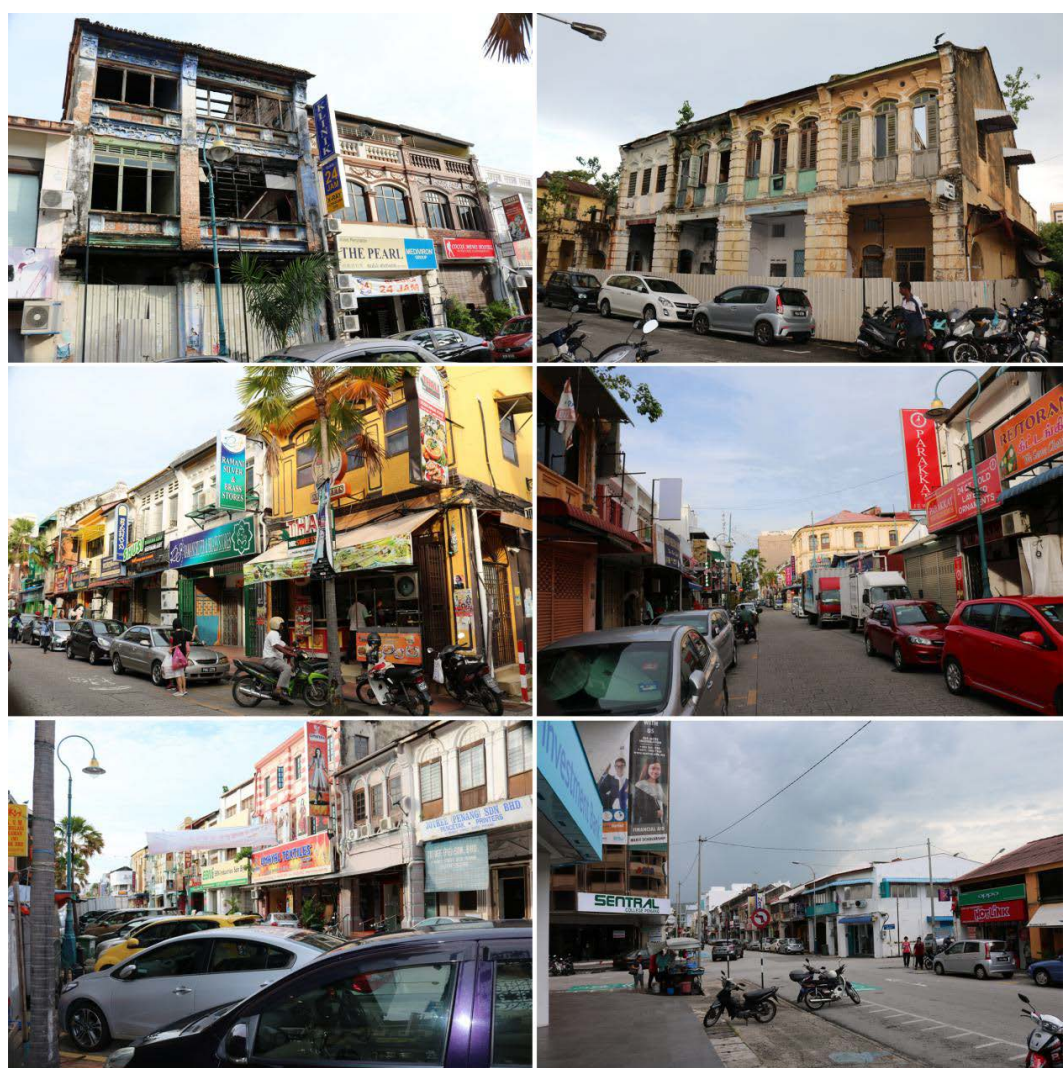

Figure 4. Dilapidated shophouses and incongruity elements in the townscape, 2016. 
the research finding shows that $78 \%$ of the historic buildings surveyed showed that the buildings were not being conserved properly according to the basic principles and conservation guidelines, and more specifically $45 \%$ of the historic buildings surveyed were categorized as shophouses [44].

Townscape is complex phenomena. Keeping in view the previous research, local scholar notes that the challenges George Town faces today, can be summarize in three facets: demographic changes, structural changes, and environmental changes [45]. As demonstrated in Figure 4, these changes have caused the loss of authenticity and cultural integrity in the townscape. However, an interesting observation is that, the governments have often given serious attention to the economic benefits from heritage tourism, but less motivation on the authenticity and cultural integrity in overall townscape. Taylor, K. and Jane, L. (2011) addresses that this is an attitude we must correct if we are ever going to succeed in placing culture where it rightfully belongs, as the foundation of development [46].

In George Town, public policies and conservation plans oppose any demolition in the shophouse blocks, to some extent, avoid the large-scale construction of real estate and commercial development projects which are incompatible with historic features. However, there is a sharp contrast between heritage conservation and urban development. the present legislation on historic buildings is not sufficient and suitable to protect shophouses from being renovated, refurbished or even demolished and destroyed. With the reconstruction and demolition of the shophouse, the integrity and authenticity of the original townscape replaced by the landscape with artificialization and homogenization. Inevitably, a large number of cultural symbols moved out from the physical environment.

3) Disneyfication: built heritage as tourism products. Policies of conservation that have led us to as tourism products are the reason for our relative lack of success in conservation. George Town Heritage Action (GHTA) group addresses that George Town cultural heritage district tends to "Disneyfication", like a theme Park after listed in the World Heritage List, and more specifically, notwithstanding that George Town attracts a lot of excursionists for sightseeing every year, however, and another half of tourists which pursue culture-oriented travels are lost [47]. Many heritage buildings still remain in poor conditions, and the conservation practice related to the maintenance of heritage building is insufficient, resulting in poor maintenance management practice. Although there is much legislation that related to conservation, the actual effect is still obscure. More benefits from the tourism, but less financial support repay to the townscape.

4) Degradation of urban aesthetic quality caused by environmental deterioration. Development densities and types, distinctive neighborhoods and commercial districts, unique architectural elements, prominent public institutions/landmarks, and other elements all contribute to the George Town's unique aesthetic quality. At this point, such assets laid the basis for tourism industry, 
but tourism development without urban environmental protection is not a sustainable way for townscape conservation. The environmental deterioration can be presented as follows: Firstly, lack of vegetation in the shophouse blocks. It is generally asserted in the technical literature that vegetation does serve physiologically to mitigate noise effects by screening off visually the adjacent noise source [48] [49] [50], meanwhile, balance the air temperatures, and reduce the air pollution in different scales. Secondly, urban environment pollution caused by the tourism industry. Tourism industry serves as a catalyst for economic growth of tourism led economies; whereas, the flip side of coin illustrates that there are numerous hazardous effects of rapidly increasing tourism [51] [52]. Some of those hazards are environmental such as climate change, emission of greenhouse gases, water and other resources scarcity, mosquito infestation, rat infestation, excess consumption of energy etc. The environmental quality degeneration generates direct impact on urban aesthetic quality in world heritage site. The overall townscape needs tremendous support or control from the administrators when intend to achieve a sustainable heritage environment.

\section{Conclusions}

Although there is much legislation that related to conservation, there is no specific conservation act being drafted in Malaysia. The conservation of shophouse townscape is not being clearly spelled out either by the means of laws and regulations, or plans. This study highlights that with careful consideration of public policies and plans in George Town. It is possible to formulate an adequate and appropriate public policies and plans that facilitate townscape conservation in a dynamic background. Several strategies in this study can be applied to achieve this goal. It is hoped that the findings may be of value to urban planners, policy-makers, and conservation experts elsewhere as they view historic townscape as the chances for urban reinvigoration. Besides, policy makers, urban planners, city developers, architects, preservationists, property owners, investors, and concerned citizens should work together to conserve the townscape in a rational way, while considering the modernization and development of society in a culturally and historicity sensitive manner, strengthening identity and social cohesion. In this process, the national, state and local heritage administration department should join policies, plans, techniques, people, culture, environment, and the economy together and enforce them effectively.

At present, the public policies and plans in relation to the townscape are in the transition period, there is an obvious change from "what to conserve" to "how to conserve", and conservation works move from building conservation to the management of overall townscape. During the transition period, firstly, various contradictions and problems are constantly revealed due to inadequate public policies; secondly, as governmental policies change with the passage of time, it is essential to continually monitor the utility and effectiveness of those policies. The emergence of new problems that have never been mentioned in the previous 
policies or plans needs to be solved urgently. Such limitations and issues reflect the careless omissions of George Town's heritage conservation system and need to improve constantly to meet the new changes. In this sense, the governments should balance the relationship among townscape, cultural heritage significance, and tourism, and then give way to the sustainable heritage development to achieve a better townscape conservation practice.

Future academicians can conduct further studies in sustainable heritage environment regard to townscape to validate the findings of the current study in George Town, Pulau Pinang. Future research can be particularly useful in keeping track of the varying impact of changes in tourism development and heritage policies. Moreover, an active and on-going research is crucial not only for furthering green tourism but also for striking the right balance among townscape, cultural heritage significance, and tourism which refer to heritage sustainability, industry sustainability and urban sustainability. Hence, future researchers can engage in research that examines the interconnected variables through public policies and plans toward townscape in dynamic management mechanism.

\section{Conflicts of Interest}

The authors declare no conflicts of interest regarding the publication of this paper.

\section{References}

[1] Ghafar, A.A. (1998) Urban Tourism in Malaysia: Heritage Cities of George Town, Malacca and Kota Bharu. The 2nd International Seminar on European Architecture and Town Planning outside Europe (Dutch Period), Malacca.

[2] Fortuna, D.R. and Maria, D.P. (2013) Historic Urban Landscape Approach and Port Cities Regeneration: Naples between Identity and Outlook. Sustainability, 10, 4268-4287.

[3] Mardziah, K. and Azree, O.M. (2012) Building Condition Assessment and Defect Analysis of Heritage Shophouses in Penang, Malaysia: Case Studies. International Journal of Engineering, 10, 441-444.

[4] Wan Hashimah, W.I. and Shuhana, S. (2005) The Old Shophouses as Part of Malaysian Urban Heritage: The Current Dilemma. The 8th International Conference of the Asian Planning Schools Association, Penang.

[5] Wong, Y.C. and Widodo, J. (2016) Shophouse/Townhouse: Asian Perspectives. National University of Singapore Press, Singapore.

[6] Lung, D.P.Y. (2016) Vernacular Architecture of Asia Tradition, Modernity and Cultural Sustainability.

https://www.edx.org/course/vernacular-architecture-asia-tradition-hkux-hku02-2x

[7] Khoo, S.N. and Halim. B. (2009) Heritage House of Penang. Marshall Cavendish International (Asia) Private Limited, Singapore.

[8] Al-Obaidi, K.M., Sim, L.W., Ismail, M.A. and Kenn, J.K. (2017) Sustainable Building Assessment of Colonial Shophouses after Adaptive Reuse in Kuala Lumpur. Buildings, 87, 1-18. https://doi.org/10.3390/buildings7040087

[9] Sharp, T. (1940) Town Planning. Pelican Publishing Company, Gretna. 
[10] Wolfe, I.D. (1963) The Italian Townscape. Architectural Press, London.

[11] Engler, M. (2015) Cut and Paste Urban Landscape: The Work of Gordon Cullen. Routledge, London. https://doi.org/10.4324/9781315725970

[12] Cullen, G. (1961) The Concise Townscape. Architectural Press, London.

[13] Laurence, P.L. (2011) Jane Jacobs, The Townscape Movement, and the Emergence of Critical Urban Design. In: Alternative Visions of Post - War Reconstruction, Routledge, London, 1-23.

[14] Jacobs, J. (2011) Downtown Is for People (Fortune Classic, 1958). http://fortune.com/2011/09/18/downtown-Is-for-people-fortune-classic-1958/

[15] McHarg, I.L. (1958) Research Proposal Notes under the Heading "Townscape". University of Pennsylvania Architectural Archives, Philadelphia.

[16] Ward, P. (1968) Conservation and Development in Historic Towns and Cities. Oriel Press, Newcastle upon Tyne.

[17] Alexander, C. (1979) The Timeless Way of Building. Oxford University Press, New York.

[18] Laws of Malaysia (2006) Control of Rent Act 1966 (Act 363) Published by the Commissioner of Law Revision, Malaysia under the Authority of the Revision of Laws Act 1968 in Collaboration with Percetakan Nasional Malaysia Bhd.

[19] Atsumi, S. (2003) The Repeal of Rent Control in Malaysia. Cornell Real Estate Review, 2, 29-38.

[20] Jenkins, G. and King, V.T. (2003) Heritage and Development in a Malaysian City: George Town under Threat? Indonesia \& the Malay World, 31, 44-57. https://doi.org/10.1080/13639810304441

[21] Lee, K.C. (1998) Urban Renewal after the Control of Rent Act 1966: Case Study of George Town. Unpublished Thesis, Universiti Sains Malaysia, Penang.

[22] Malaysia Ministry of Finance. Property Market Report. Kuala Lumpur, Various Years.

[23] Hwa, M.S. (2000) Focus on Tenant at Large. The Star, A.

[24] Choong, K.K. (2000) Mobilize Social Workers for Crisis. The Star, A.

[25] Laws of Malaysia (2006) National Heritage Act. Published by the Commissioner of Law Revision, Malaysia under the Authority of the Revision of Laws Act 1968 in Collaboration with Percetakan Nasional Malaysia Bhd.

[26] Bakri, F., Norhati, I.S. and Nurulhusna, Q.Z. (2014) Valuing Built Cultural Heritage in a Malaysian Urban Context. Environmental Settings in the Era of Urban Regeneration Asian Conference on Environment-Behaviour Studies. Chung-Ang University, Seoul.

[27] Municipal Council of Penang (2005) Guidelines for Conservation Area and Heritage Buildings by the Municipal Council of Penang. http://penangshophouse.com.my/?page_id=106

[28] State Government of Penang (2008) Historic City of George Town Heritage Management Plan. Badan Warisan Heritage Services Sdn Bhd, Kuala Lumpur.

[29] State Government of Penang, Municipal Council of Penang, GTWHI, JPBD (2016) Special Area Plan: George Town, Historic Cities of the Straits of Malacca. Warta Kerajaan Jilid 60 No. 18 Tambahan No. 1 Bertarikh.

[30] Laws of Malaysia (1976) Antiquities Act 1976. Kuala Lumpur Dicetak Oleh Pemangku Ketua Pengarah Percetakan Dan Diterbitkan Dengan Perintah Pada. 
[31] Lei, S.C. (2017) George Town, Malaysia: Losing Old Luster as New Developments Come In? https://www.benarnews.org/english/news/malaysian/george-town-03032017162352. $\underline{\mathrm{html}}$

[32] Nora, M., Mechtild, R. and Pierre, M.T. (2009) World Heritage Cultural Landscapes: A Handbook for Conservation and Management. UNESCO World Heritage Centre, Paris.

[33] UN (2016) Issue Papers of the United Nations Conference on Housing and Sustainable Urban Development.

http://habitat3.org/the-new-urban-agenda/documents/issue-papers/

[34] Hussein, N.A. (2017) Conservation of Cultural Built Heritage: An Investigation of Stakeholder Perceptions in Australia and Tanzania. Ph.D. Thesis, Bond University, Queensland.

[35] Steinberg, F. (2008) Revitalization of Historic Inner-City Areas in Asia: The Potential for Urban Renewal in Ha Noi, Jakarta and Manila. Asia Development Bank, Manila.

[36] Wu, X.A. (2011) Immigrants, Ethnic Groups and Identification: Historical Characteristics and Development Momentum of Chinese Dialect Groups in Southeast Asia. In: Ethnic Groups, History, and Culture: Cross Regional Study of Southeast Asia and East Asia, Joint Publication of the Chinese Department of National University of Singapore \& World Science and Technology Publishing Company, Singapore, 3-22.

[37] Henderson, J. (2012) Conserving Heritage in South East Asia: Cases from Malaysia, Singapore, and the Philippines. Tourism Recreation Research, 1, 47-55. https://doi.org/10.1080/02508281.2012.11081687

[38] Henderson, J. (2011) Understanding and Using Built Heritage: Singapore's National Monuments and Conservation Areas. International Journal of Heritage Studies, 1, 46-61. https://doi.org/10.1080/13527258.2011.524006

[39] Lyn, L.E., Richard, M. and Heather, B. (2004) Understanding Cultural Landscapes. http://ehlt.flinders.edu.au/humanities/exchange/asri/define_cl.html

[40] Jenkins, G. (2008) Contested Space: Cultural Heritage and Identity Reconstructions: Conservation Strategies within a Developing Asian City. LIT Verlag Münster, Münster.

[41] Hsu, Y.T. (2015) The Role of Memorial Parks: Creation of Cultural Landscape and Historical Consciousness in Chinese Communities in Sibu, Sarawak, Malaysia. The International Journal of Diasporic Chinese Studies, 1, 63-87.

[42] Pong, T.K. (2011) Ethnic Contestation and Cultural Adaptation in Plural Society: A Study of the Cultural Interaction of Malaysian Chinese and Malay. In: Proceedings of the 2011 SINO-ASEAN Conference on Cross-Culture Communication, Guizhou University for Nationalities, Guiyang, 95-109.

[43] Kamal, K.S., Wahab, L.A. and Ghafar, A.A. (2008) Pilot Survey on the Conservation of Historical Buildings. In: Proceedings of the 2nd International Conference on Built Environment in Developing Countries, Universiti Sains Malaysia, Penang, 2-13.

[44] Jokilehto, J. (2006) Considerations on Authenticity and Integrity in World Heritage Context. City \& Time, 1, 1-16.

[45] Lee, L.M., Lim, Y.M. and Nor'Aini, Y. (2008) Strategies for Urban Conservation: A Case Example of George Town, Penang. Habitat International, 32, 293-304. 
https://doi.org/10.1016/j.habitatint.2007.09.001

[46] Taylor, K. and Jane, L. (2011) Cultural Landscapes: A Bridge between Culture and Nature. International Journal of Heritage Studies, 6, 537-554. https://doi.org/10.1080/13527258.2011.618246

[47] Opalyn, M. (2016) "Disneyfication" of George Town Will Hurt Economy. Penang Heritage Group Cautions.

https://www.malaymail.com/s/1166281/disneyfication-of-george-town-will-hurt-ec onomy-penang-heritage-group-cauti

[48] Herrington, L.P. (1974) Trees and Acoustics in Urban Areas. Journal of Forestry, 72, 462-465.

[49] Reethof, G. and Heisler, G.M. (1976) Trees and Forests for Noise Abatement and Visual Screening. Better Trees for Metropolitan Landscape, USDA For. Serv. Gen. Tech. Rpt. NE-22.

[50] Richard, C.S. (1988) Perception and Aesthetics of the Urban Environment: Review of the Role of Vegetation. Landscape and Urban Planning, 15, 85-106. https://doi.org/10.1016/0169-2046(88)90018-7

[51] Mowforth, M. and Munt, I. (2016) Tourism and Sustainability: Development, Globalisation and New Tourism in the Third World. Routledge, New York.

[52] Azam, M., Mahmudul Alam, M. and Haroon Hafeez, M. (2018) Effect of Tourism on Environmental Pollution: Further Evidence from Malaysia, Singapore and Thailand. Journal of Cleaner Production, 190, 330-338.

https://doi.org/10.1016/j.jclepro.2018.04.168 